Article

\title{
Cluster Analysis Applied to Spatiotemporal Variability of Monthly Precipitation over Paraíba State Using Tropical Rainfall Measuring Mission (TRMM) Data
}

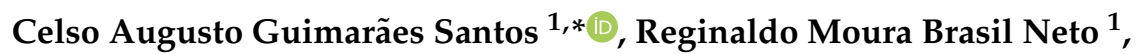 \\ Richarde Marques da Silva ${ }^{2} \mathbb{D}$ and Samir Gonçalves Fernandes Costa ${ }^{1}$ \\ 1 Department of Civil and Environmental Engineering, Federal University of Paraíba, João Pessoa 58051-900, \\ PB, Brazil; regismouraneto@hotmail.com (R.M.B.N.); samir-gfcost@hotmail.com (S.G.F.C.) \\ 2 Department of Geosciences, Federal University of Paraíba, João Pessoa 58051-900, PB, Brazil; \\ richarde@geociencias.ufpb.br \\ * Correspondence: celso@ct.ufpb.br; Tel.: +55-83-3216-7684
}

Received: 11 January 2019; Accepted: 5 March 2019; Published: 15 March 2019

\begin{abstract}
In Paraíba state, precipitation is strongly affected by several climate systems, such as trade winds, the intertropical convergence zone (ITCZ), easterly wave disturbances (EWDs), and the South Atlantic subtropical high. Accordingly, the objective of this study was to analyze the spatiotemporal variability in precipitation to identify homogeneous trends of that variable and the effects of climate systems in Paraíba state by cluster analysis. The precipitation data used in this study derive from the Tropical Rainfall Measuring Mission (TRMM) satellite for the period from January 1998 to December 2015, and hierarchical clustering was used to classify the sites into different groups with similar trends. The findings show an uneven spatiotemporal precipitation distribution in all mesoregions of the state and considerable monthly precipitation variation in space. The estimated precipitation depth was highest in coastal regions and in high-altitude areas due to orographic precipitation. In general, the precipitation over Paraiba is characterized by strong gradients in the coastal zone towards the continent (Agreste, Borborema, and Sertão mesoregions) and from north to south due to the physiography of the region and the effects of climate systems with different time scales. Finally, the proposed clustering method using TRMM data was effective in characterizing climatic systems.
\end{abstract}

Keywords: cluster; Paraíba; rainfall; TRMM

\section{Introduction}

Precipitation is considered the most important meteorological variable for farming, water supply, and human life; therefore, understanding the spatiotemporal behavior of that variable has attracted the attention of various researchers who conduct studies to identify the occurrence of extreme phenomena such as droughts and floods. Regarding droughts, the arid and semiarid regions need further research [1-4] because they are susceptible to natural disasters caused by droughts and climate change. According to Farhangi et al. [5], the main problem in these regions is not necessarily the rainfall deficit but rather its high spatial and temporal variability as well as its intensity and duration.

In South America, the northeastern region of Brazil has been historically affected by water shortages, especially in its semiarid region [6-8]. The semiarid region of Brazil is the most populous in the world, having more than 24 million inhabitants and a high population density [9], and is considered among the areas most vulnerable to recurrent droughts worldwide [10]. The drought from 2011 to 2017 was one of the most severe in recent decades in this region, affecting approximately 9 million 
people [11]. In addition, Cunha et al. [10] identified that in the period 1982-2016, three of the five most severe drought events over the semiarid region of Brazil (1997-1998, 2007-2008, and 2012-2015) occurred in the period 1998-2015. Therefore, it is important to evaluate the rainfall patterns in this specific period over Paraíba state for social development and to mitigate the damaging effects of the droughts.

Paraiba state is almost fully located in the semiarid region of northeastern Brazil and is frequently affected by droughts [4]. In this region, subsistence farming is carried out, which provides food for and economically supports small farmers, especially in less developed areas. Thus, considering the harmful effects of droughts that frequently affect the population of the semiarid region of Brazil, several statistical methods combined with the geographic information system and remote-sensing products have been developed and used to analyze the spatiotemporal trends of precipitation.

Among the statistical methods used to investigate the spatiotemporal variations of climatological variables, application of multivariate techniques by cluster analysis to delimitate homogeneous regions and to identify regional and global climate patterns has been increasing in recent years [12]. The application of this tool is among the most used approaches in the literature on clustering processes (e.g., [13-16]), and the relevance of this technique is closely related not only to the quality and types of variables that can be grouped under different aspects but also to the identification of similarity and dissimilarity patterns among study variables. Thus, due to the flexibility of combinations of similarity methods and metrics, hierarchical cluster analysis is suitable for different purposes and situations, which makes its application comprehensive and effective for different types of variables and studies.

In the study conducted by Unal et al. [13], for example, different hierarchical clustering methods were tested using precipitation and temperature data to define climate zones in Turkey, and seven different climate regions were found. In Brazil, Lyra et al. [14] analyzed the rainfall in the state of Alagoas, which is also located in northeastern Brazil, using hierarchical cluster analysis and spatiotemporal rainfall patterns based on 36 precipitation time series. The results indicated that the cluster analysis method adequately identified five homogeneous regions as well as precipitation trends and active climate systems in each region. In the central region of Brazil, Teodoro et al. [17] analyzed the spatiotemporal variability in rainfall by hierarchical cluster analysis to identify the meteorological systems that affect the rainfall regime of biomes in the state of Mato Grosso do Sul. The results were also effective, identifying five different homogeneous regions regarding the rainfall trends in the study area. For example, such identification of homogeneous regions, based on precipitation records, would be useful to assist decision-making regarding the adoption of plans to be applied to the water management in cities and reservoirs within the same cluster. Thus, each cluster would have a specific plan to combat the implications of drought.

However, long, consistent, and faultless data series capable of capturing the rainfall regime and climatic variations of these regions are necessary to apply clustering methods to meteorological variables. Accordingly, among the products most often used to analyze the precipitation trends are those derived from the Tropical Rainfall Measuring Mission (TRMM), which is known for generating uninterrupted estimates of precipitation data since 1998, making them available through different products and spatiotemporal resolutions for the tropics [18-20]. Among many satellite-based precipitation products, e.g., the Precipitation Estimation from Remotely Sensed Information using Artificial Neural Networks (PERSIANN), the Climate Prediction Center (CPC) Morphing (CMOPRH) and Global Precipitation Measurement Mission (GPM), the TRMM multisatellite precipitation analysis (TMPA) precipitation estimates were reported to perform the best among them in the TRMM era [21,22].

The main advantage of using TRMM products in the present analysis is because it provides long, consistent, faultless, and uniformly distributed precipitation time series throughout Paraíba state [4]. Precipitation estimates generated by the TRMM satellite have been validated with rainfall data in Brazil and worldwide and are already being used as a database for the development of several studies in the field of water resources [23-25]. For example, Islam and Uyeda [26] recently determined the 
climate characteristics of rainfall over Bangladesh, and Santos et al. [4] evaluated the short-, medium-, and long-term drought conditions and trends in Paraíba state using TRMM data.

Cattani et al. [15] evaluated six satellite-derived precipitation products over East Africa to investigate precipitation seasonality from 2001 to 2009 in the region. Based on the results, eight different areas (clusters) were delimitated, and the 3B42 product of the TRMM satellite was the most notable for its performance. In a similar study, Corporal-Lodangco and Leslie [16] used TRMM satellite data to apply cluster analysis and to determine the optimal number of homogeneous clusters to identify climate zones in the Philippines.

As discussed by Omranian and Sharif [27] on a study evaluating three different GPM products over a region of Texas, the change in spatiotemporal resolution of satellite precipitation products directly affects the accuracy of the satellite estimates. In general, the longer the data accumulation period and the less refined the spatial resolution are, the accuracy of the precipitation estimates obtained by remote sensing is better. In Paraíba, Soares et al. [28] have already tested the accuracy between TRMM satellite and rain gauges data for identifying rainfall regimes over time, using some statistical metrics, e.g., bias, root mean squared, and correlation coefficient. The results for different spatiotemporal scales showed that especially on a monthly scale, which is the timescale used in this study to cluster regions with homogeneous characteristics, the TRMM 3B42 product presented good statistical accuracy (correlation coefficient $>0.8$ ). However, despite the usefulness of knowing the spatiotemporal patterns of precipitation, no study is known to have assessed in more detail the spatiotemporal precipitation trends in this region of Brazil by cluster analysis, and the zoning proposed in this study is important for the development of further studies related to water resources in the region.

Some studies reported in the literature could not analyze in depth the spatial variation of the monthly precipitation due to its complexity. In the study by Teodoro et al. [17], for example, five different homogeneous regions are identified over a region of northeastern Brazil, albeit without analyzing how those groups interact with each other each month or their inter-monthly variation. The same gap is found in the study conducted by Macedo et al. [29] in Paraíba state. In that study, although homogeneous regions were clustered based on k-means clustering, a breakdown of the inter-monthly variation across the state is still needed.

By reflecting on this and other knowledge gaps identified in studies on precipitation behavior that may be bridged, the cluster analysis proposed in this study is relevant because it enables not only the identification of homogeneous regions considering the entire study period (1998-2015) but also the evaluation of the similarity and dissimilarity between regions in each month, thereby facilitating the identification of the climate systems active in each region. Thus, by considering the water shortage problem in Paraíba in the last two decades, this study aims to analyze the precipitation variability using data estimated by the TRMM satellite to identify homogeneous precipitation trends and the climate systems active in Paraiba state by applying the statistical method of cluster analysis. The intention is to bridge knowledge gaps found in other studies and to understand how the regional monthly rainfall trends are affected by climate systems.

\section{Materials and Methods}

\subsection{Study Area}

Paraíba is a state in northeastern Brazil that is located between coordinates $5.875^{\circ} \mathrm{S}$ and $8.625^{\circ} \mathrm{S}$ and $38.875^{\circ} \mathrm{W}$ and $34.625^{\circ} \mathrm{W}$, which is almost entirely within the semiarid region of Brazil (Figure 1). Paraíba has an area of $56,469.78 \mathrm{~km}^{2}$ and a total of 223 municipalities, and is subdivided into four geographical mesoregions: Agreste Paraibano, Borborema, Mata Paraibana, and Sertão Paraibano. According to Köppen's climate classification, Paraíba has climate types As' (with dry summer) and BSh (low latitude and altitude) [30]. The Mata Paraibana and Agreste Paraibano mesoregions are characterized by the subtypes As' and Aw (dry winter); Borborema, part of the Agreste Paraibano 
and the far north of the Sertão Paraibano, is characterized by subtype BSh (semiarid climate); and the subtype As' (warm and semihumid or subhumid climate), which is characterized by high mean temperatures ranging from 22 to $30^{\circ} \mathrm{C}$ and by a very narrow annual range, due to the low latitude and elevation $(<700 \mathrm{~m})$, occurs in most of the Sertão Paraibano [31].

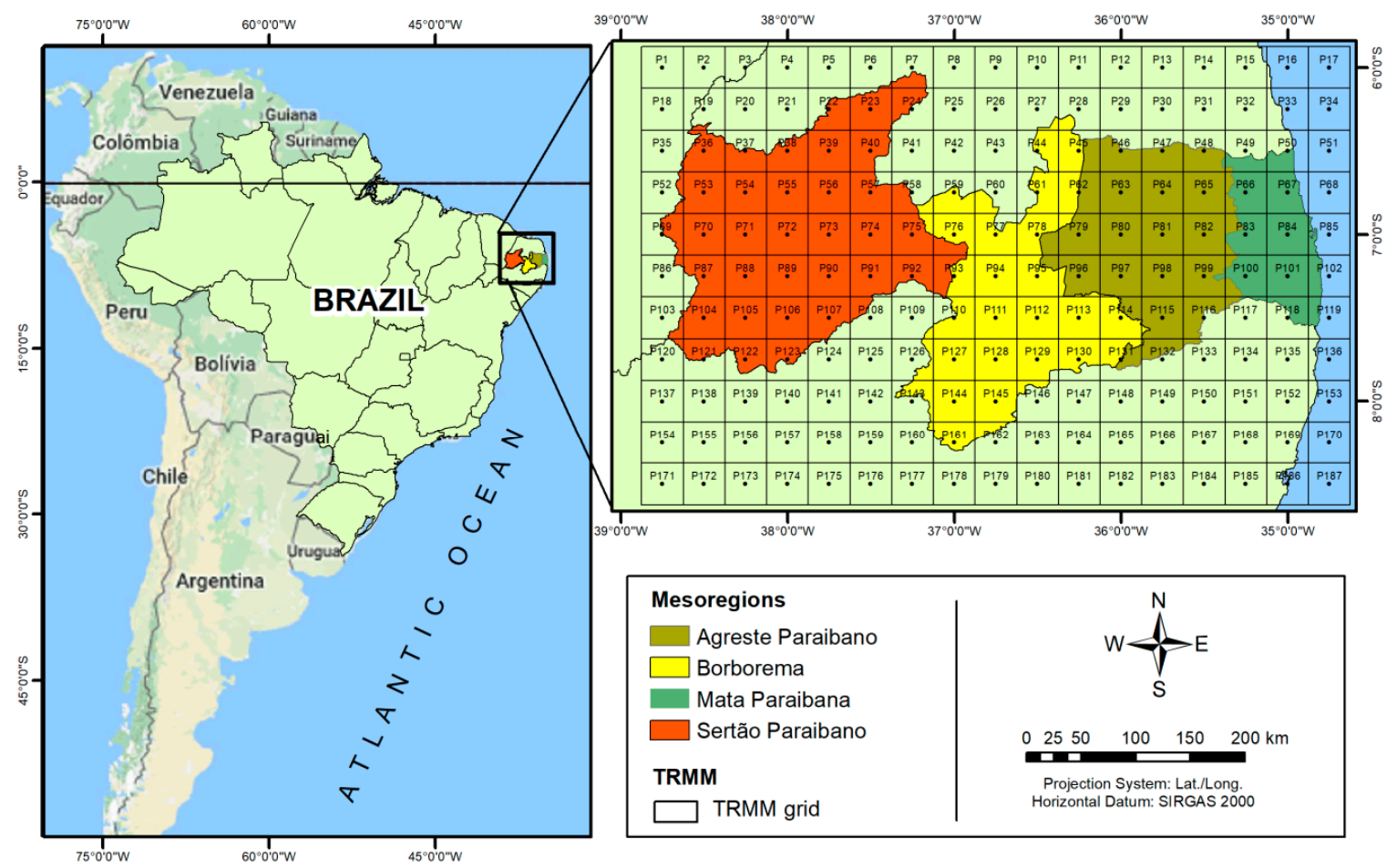

Figure 1. Locations of Paraíba state, its mesoregions, and the study area and the distribution of the 187 grid cells of the Tropical Rainfall Measuring Mission (TRMM) time series data.

Northeastern Brazil is characterized by a complex climate heterogeneity. Regarding the active climatic systems, Kousky [32] identified macro-, meso-, and microscale phenomena that influence the precipitation on Paraíba state. The major macro-scale precipitation generator is the Intertropical Convergence Zone (ITCZ), which is related to the Northern Disturbed Currents [33]. The ITCZ depicts the rise of hot and humid air, which is derived from the convergence of the trade winds, where the humidity of the ocean will be displaced to the high levels of the troposphere, causing cloud formation. Still about macro-scale phenomena, another active system in the area is the upper tropospheric cyclonic vortices (UTCVs), which is a set of circle-shaped clouds rotating clockwise, where at the center occur the subsiding air movements, causing rainfall inhibition and pressure, which generates cloud formation, and consequently precipitation [34]. On the other hand, the trade wind disturbance and the convective complexes are the mesoscale systems and as far as microscale systems are concerned, the orography is the one with the greatest expressiveness [35], because the relief is considered in this context as a topographic barrier for migratory masses of air, where air will ascend on the mountain and cool, resulting in the formation of stratiform clouds, which causes a lot of rainfall in the coastal zone and little precipitation in the Sertão.

Regarding its physical geography, Paraíba state has a well-differentiated terrain, particularly in the following morphological units: (a) Coastal Tablelands, (b) Borborema Plateau, (c) Sertão Plateau, (d) Sertão Depression, (e) Residual Plateaus, and (f) Plains (Figure 2). Each of these terrain units consists of different geological formations due to precipitation and temperature erosion of the rocks. The altitudes in the region increase from east to west until the Borborema Plateau and decrease from the Sertão Depression. 


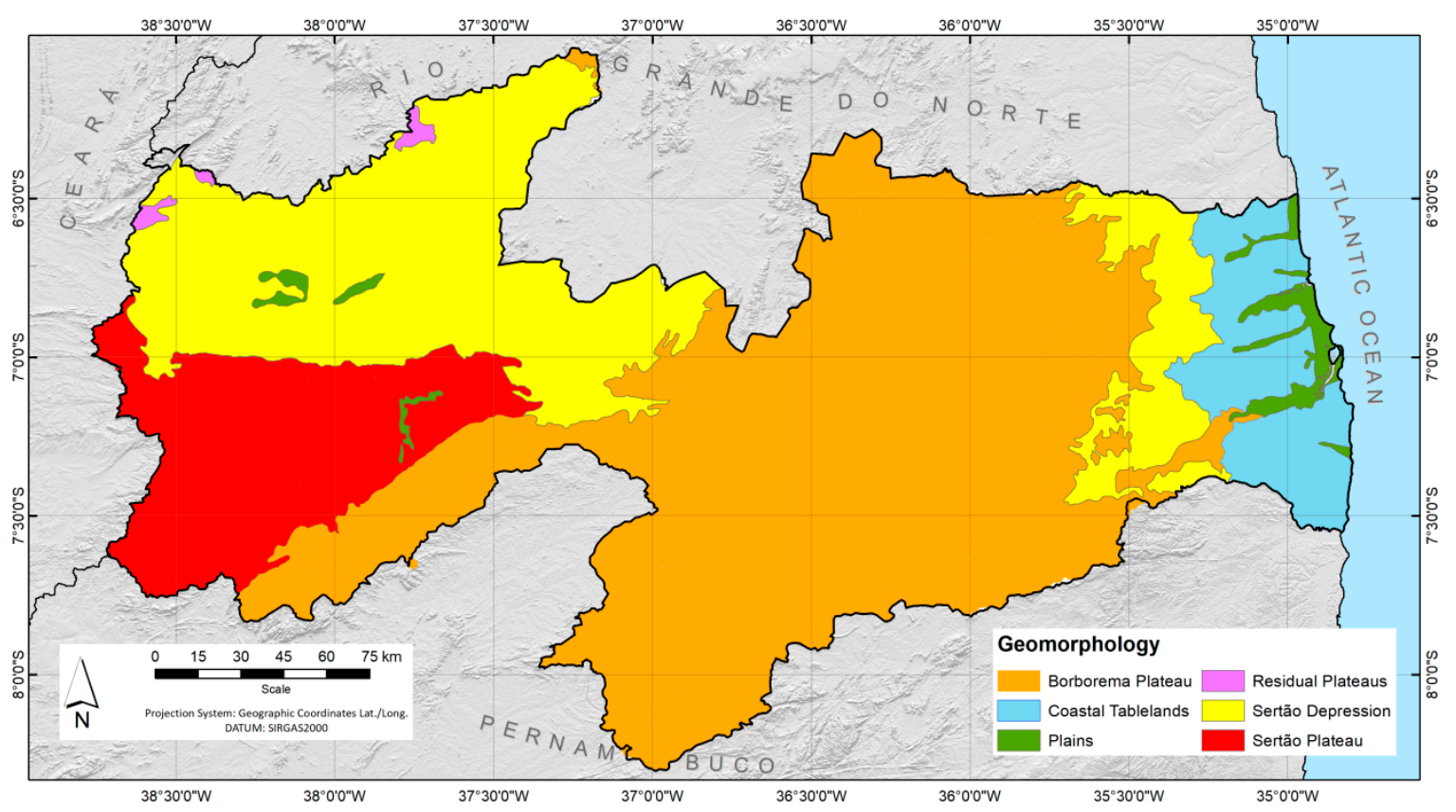

Figure 2. Paraíba state morphological units.

The Borborema Plateau is the highest terrain of Paraíba (400 to 1000 m), covering most of Paraíba, and consists of several mountains, including the highest point of Paraíba, the summit of Pico do Jabre, which is $1197 \mathrm{~m}$ above sea level. Conversely, the Sertão Depression is formed by a group of lowlands and also encompasses a vast area that is mostly located in the Sertão Paraibano mesoregion. The coastal elevation classes range from 0 to $200 \mathrm{~m}$ (Coastal Tablelands, Residual Plateaus, and Plains), with altitudes ranging from 200 to $400 \mathrm{~m}$ in the Sertão Depression in the western section of the state.

Temperature analysis showed that the lowest values occur in the Agreste Paraibano and Sertão Paraibano mesoregions, with a spatial variation that is directly dependent on the terrain and air masses, with mild temperatures occurring in the higher areas, whereas the depressions are essentially hot. Thus, the ranges of temperature for each mesoregion are as follows: Sertão Paraibano $\left(21\right.$ to $\left.28^{\circ} \mathrm{C}\right)$, Borborema $\left(23\right.$ to $\left.27^{\circ} \mathrm{C}\right)$, Agreste Paraibano $\left(22\right.$ to $25^{\circ} \mathrm{C}$ ) and Mata Paraibana (24 to $\left.27^{\circ} \mathrm{C}\right)$ [28]. Lastly, relative to the latitude variation, temperatures in Paraíba are considered high throughout the year, with small regional variations.

\subsection{Precipitation Data}

The precipitation data used in this study are daily estimates generated every $3 \mathrm{~h}$ by the 3B42 (version 7) algorithm of the TRMM satellite, with $0.25^{\circ}$ spatial resolution and with a time range from 1 January 1998 to 31 December 2015. This product is considered to be a highly recommended source by Huffman and Bolvin [20], especially in cases where surface data are difficult to obtain or insufficient, when contending with an uneven spatial distribution of rain gauges, or when there are missing data in historical series, as is the case of Paraíba, as analyzed by Santos et al. [4]. The data used in this study are daily values aggregated to obtain monthly values and derive from 187 TRMM grids located within the rectangle defined by the coordinates from $38.875^{\circ} \mathrm{W}$ to $34.625^{\circ} \mathrm{W}$ and from $5.875^{\circ} \mathrm{S}$ to $8.625^{\circ} \mathrm{S}(11 \times$ 17 grid), where Paraíba state is located (Figure 1). It is worth noting that Santos et al. [4], using the same monthly TRMM 3B42 data (1998-2015) over the Paraíba state, observed correlation values higher than 0.8 between TRMM and gauge rainfall data on a monthly basis for Paraíba state in the entire period, which confirmed the high accuracy of this TRMM product. 


\subsection{Cluster Analysis}

Cluster analysis is an important statistical tool for clustering homogeneous regions. Cluster analysis can be performed using two different methods, which are based on hierarchical and non-hierarchical techniques [13]. In general, hierarchical methods have been gaining prominence in recent years because of the variety of existing clustering methods and the number of dissimilarity metrics available to categorize different variables into homogeneous groups [13]. By applying those methods, clusters are created, which are defined as groups formed by different objects related to each other according to a clustering method and to a specific metric of similarity between the climatological variables being analyzed.

The clustering method refers to the way in which the distance between the defined clusters are calculated. The most commonly used hierarchical methods include single linkage, complete linkage, centroid, Ward's minimum variance, and the mean distance method. Dissimilarity metrics, in turn, refer to the statistical measures that relate each element that will form each group, thus creating each specific cluster, and include Euclidian distance, correlation, cityblocks, and Spearman parameters. Each method and metric has its advantages and disadvantages in comparison with others, and depending on the purpose of the study, a certain combination may be more adequate than another.

Furthermore, in this context, the choice of method may also affect the distances between the defined clusters, whereas the chosen dissimilarity metric affects the relationships between rain gauges (grid points), as is the case for this study. Thus, when adopting Ward's method in different analyses, for example, a change in the metric chosen to perform the clustering may determine that, even if two rain gauges (grid points) can be considered similar and part of the same cluster, from the Euclidean distance standpoint, those gauges may show completely different behaviors and be categorized into different clusters by the correlation coefficient metric.

Similarly, when using the same dissimilarity metric, such as Euclidian distance, and two different methods for clustering regions, such as Ward's method and the mean distance method, distances between clusters will likely change significantly, thereby changing the dendrogram pattern, and the clusters may relate to each other differently, i.e., clusters and elements may no longer be as similar as before.

Presenting results in the form of a tree diagram (dendrogram) makes it possible to hierarchically depict the groups of clusters and their combinations, indicating the level of similarity/dissimilarity in the vertical scale and the sample elements in clustering order on the horizontal axis. The clustering method used in this study was the mean linkage method with correlation as the similarity metric, which usually provides satisfactory results when studying climate variables, because that method overcomes some deficiencies of other hierarchical methods in clustering homogeneous groups and, therefore, clustering is less affected by atypical observations in cluster formation, according to Unal et al. [13]. In order to compute the distance between clusters, the average method uses the average distance between all pairs of objects in any two clusters [13]:

$$
d(r, s)=\frac{1}{n_{r} n_{s}} \sum_{i=1}^{n_{r}} \sum_{j=1}^{n_{s}} d\left(x_{r i}, x_{s j}\right)
$$

where $d(r, s)$ is the distance between clusters $r$ and $s$, and $n$ is the number of elements in each cluster. The similarity metric used in this study was correlation because this study aimed to cluster precipitation data based on their behavior over time, incorporating their temporal variations. The correlation distance is one minus the sample linear correlation between observations (treated as sequences of values). Accordingly, the two precipitation time series with the highest correlation coefficient (i.e., the lowest correlation distance) were clustered together [36]. It should be noted that, usually, the Euclidian distance metric is chosen, and thus, precipitation time series with similar means tend to be clustered together. Therefore, using the linear correlation coefficient as a dissimilarity metric is an innovative process because it makes it possible to cluster series based on data trends and variation over time, 
thereby identifying the precipitation time series over Paraíba state affected by a specific climate forcing agent in a specific month or year throughout the time series.

To analyze in more detail the spatiotemporal variability in precipitation over Paraíba state and to bridge existing knowledge gaps, the spatiotemporal variability in precipitation of each month was also analyzed using the 187 TRMM time series. More specifically, the different precipitation time series were grouped into different clusters according to their monthly precipitation in each year (totaling 12 different cluster analyses, i.e., 12 monthly grids $\times 187$ precipitation time series $\times 18$ annual values each). The development of this analysis is important because it explains the monthly precipitation trend in Paraíba state.

It is important to point that the monthly hyetographs were used to perform the cluster analysis because other studies over the area showed that this is the timescale with the highest accuracy $[4,28]$. If the cluster analysis had been performed using daily data, the results could be imprecise. The spatial resolution also influences the results; therefore, the finest resolution was used (i.e., $0.25^{\circ} \times 0.25^{\circ}$ ), which resulted in 187 time series over the study area (Figure 1), and well represents the spatial rainfall distribution throughout Paraíba state.

\section{Results and Discussion}

Figure 3 shows the spatial distribution of the mean monthly TRMM precipitation in the study area over the 18 study years (1998-2015). The results show the spatiotemporal variability of the monthly precipitation over Paraíba state, with precipitation values ranging from 0 to $300 \mathrm{~mm}$, depending on the month and on the area of Paraíba. In general, the months from January to June are the rainiest, whereas the months from July to December are the least rainy in this state. The Mata Paraibana mesoregion shows the highest precipitation values, and the Borborema mesoregion has the lowest values, regardless of the month analyzed.

Although Figure 3 clearly shows the spatiotemporal trends of precipitation in the study area, enabling the identification of the driest and rainiest months in Paraiba state, the data analysis must be refined, that is, the clustering of each of the 187 precipitation time series must be carried out. Thus, to overcome this difficulty in clustering each series analyzed into different homogeneous groups, only based on information available in the figure, cluster analysis was adopted in this study. Without applying an adequate statistical tool, such as cluster analysis, the classification of the precipitation trends into different groups may be highly subjective and inaccurate, leading to uncertain findings.

Given that limitation, the cluster analysis developed in this study addressed both the spatial and temporal variations in monthly precipitation in Paraíba state. In the spatial analysis, the 187 TRMM data series distributed in the study area were clustered in different ways to identify the regions that behaved similarly to each other, thereby explaining possible physical and climatological causes of the precipitation trends in Paraíba state. Conversely, in the temporal analysis, the monthly precipitation trend was assessed to study whether a specific month had a more similar behavior to the previous or to the following month, for example.

For the temporal cluster analysis, 12 series were organized (one for each month). Each series contained 18 values (one for each year of the series) comprising the mean monthly precipitation values over the 18 years of study throughout the study area, i.e., considering all 187 TRMM series. Figure 4 shows the dendrogram resulting from the cluster analysis of the mean monthly precipitation from 1998 to 2015. Thus, Figure 4 shows which months have similar hyetograph patterns. The monthly precipitation trend over the last 18 years is rather heterogeneous when analyzing the entire study area. However, when analyzing the results in more detail, the spatiotemporal precipitation trend on an annual scale indicates a decrease in precipitation in the last four years of the study, i.e., from 2012 to 2015, as previously reported by Santos et al. [4], which evaluated the trends of eight SPI indexes over Paraíba state (1998-2015). Although the precipitation trends were not evaluated, the analyses based on the standardized precipitation index (SPI) time series, which is based only on precipitation data, complement the analysis of precipitation data over the 18 years analyzed. 


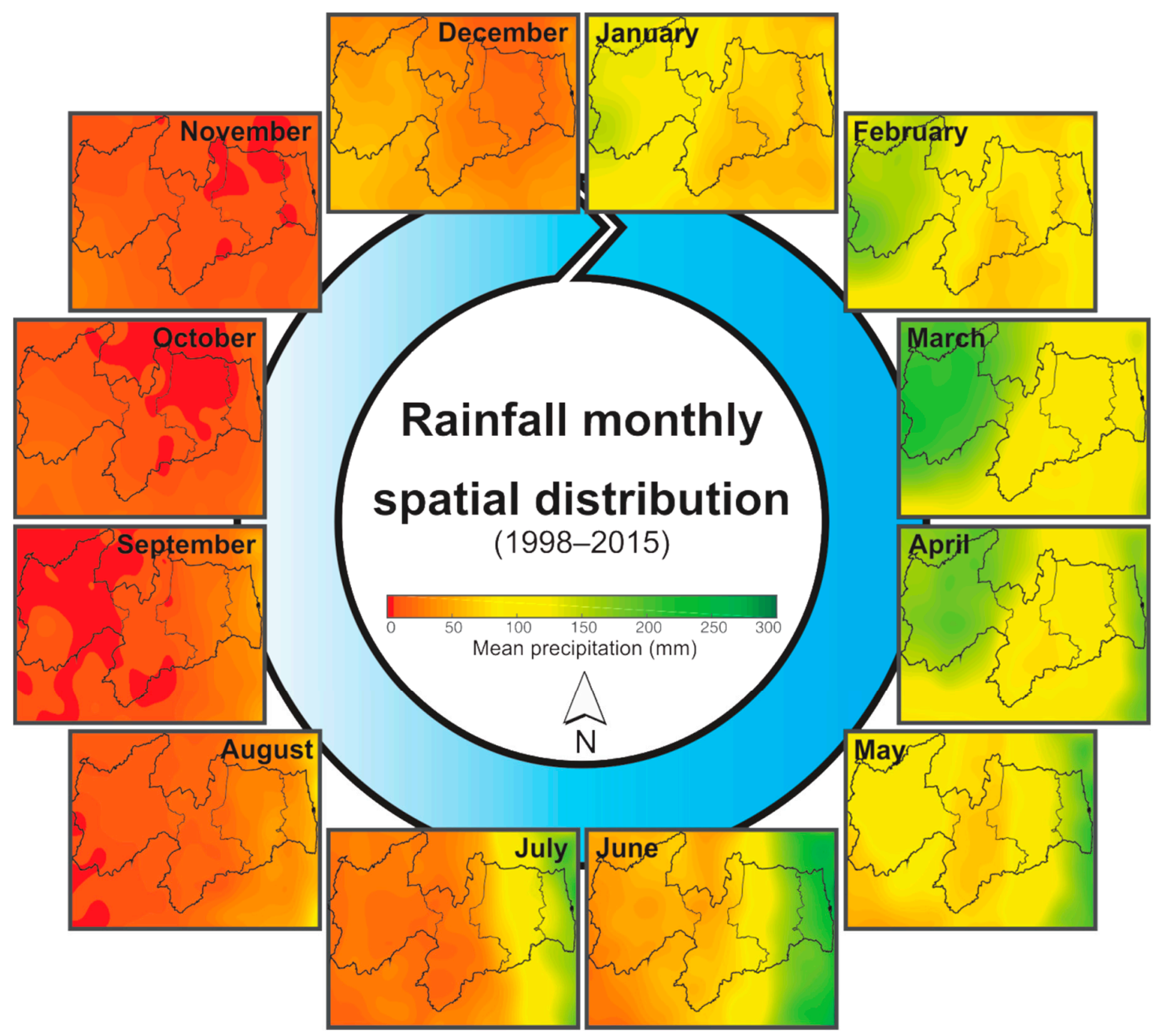

Figure 3. Spatial distribution of mean monthly TRMM precipitation in Paraíba (1998-2015).

The results in Figure 4 show that the correlation distances between monthly series are considerably high because some series are completely different from each other, such as October and November precipitation time series, which differ considerably from the precipitation trend in other months. In general, considering a correlation distance of 0.50 between series, similar to Lyra et al. [14] and to Teodoro et al. [17], the results showed the existence of nine different clusters, highlighting a rather unusual trend between the study months in the last 18 years.

In more detail, the group formed by December and June can be considered to be the cluster that represents the two transition months; December is the transition to the rainy season, and June is the transition to the dry season. Although January, February, and March are rainy months for the region, they showed a similar precipitation trend when considering a correlation distance of 0.50 , and January and February were the most similar months. April and May were highly similar to each other, as were July, August, and September, thus defining an intermediate precipitation season in Paraíba state.

Furthermore, in this context, it is worth noting that the clusters generated were based on the correlation dissimilarity metric, and had the Euclidean distance been used as the clustering metric, the findings would have certainly been different, possibly clustering the series from January, February, and March into a single cluster because the total precipitation of each of those months was higher than that of September, October, and November. 

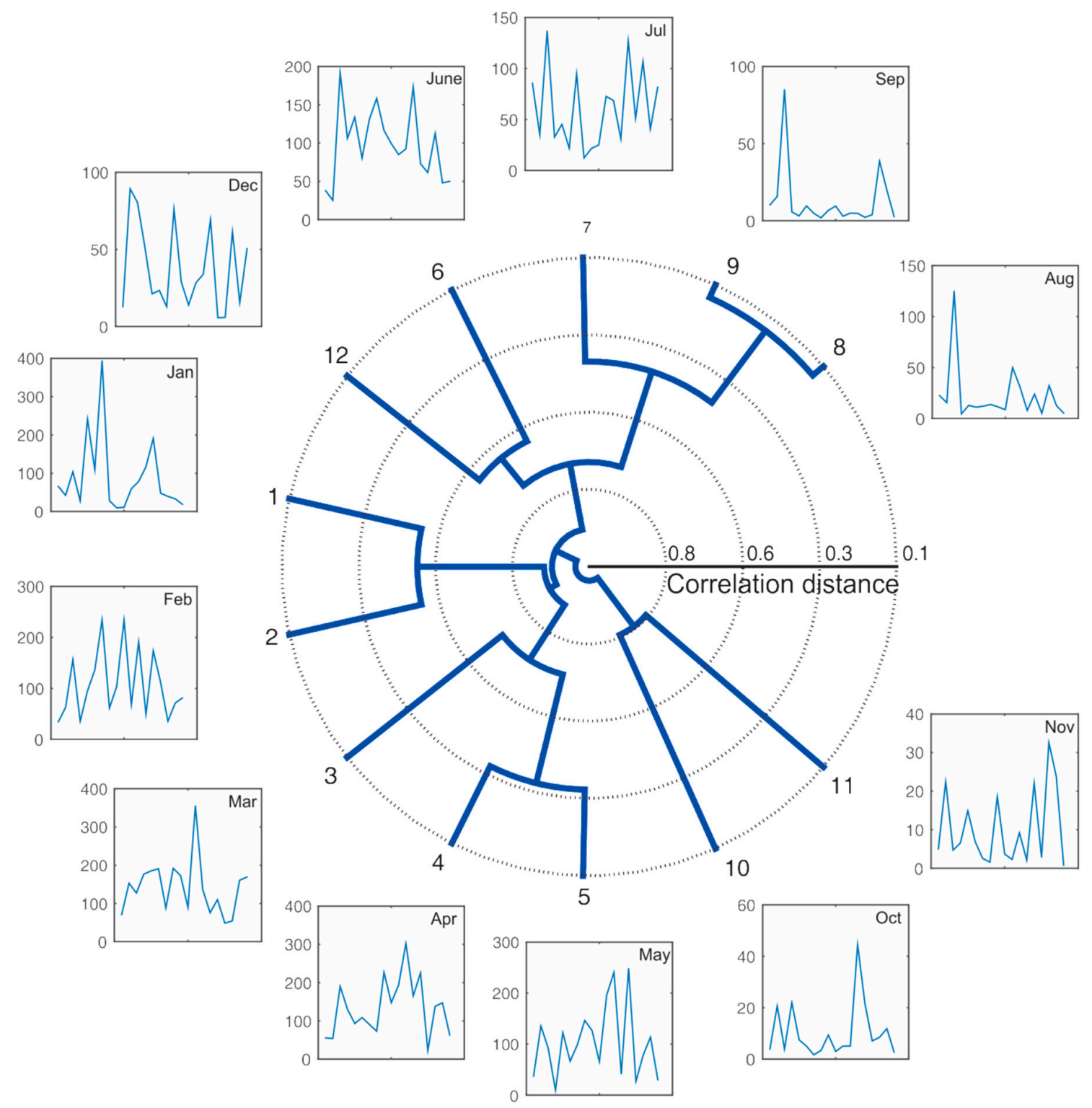

Figure 4. Dendrogram of the time series of each month from 1998 to 2015.

Another key issue is that the cluster analysis presented in Figure 4 shows the mean precipitation trend of the entire study area, including the precipitation trend of all mesoregions and their specificities in a single series of mean monthly precipitation. Making a parallel with Omranian and Sharif [27], Figure 4 was developed based on the lowest possible spatial resolution; i.e., 187 TRMM grids were aggregated. Notwithstanding, the results obtained are practical. In this context, if the finest spatial resolution would be used $\left(0.25^{\circ} \times 0.25^{\circ}\right), 187$ figures similar to Figure 4 would be necessary to fully characterize the precipitation variability in the study area, which is impractical. In the case of Paraíba, the findings using one mean monthly precipitation time series can be considered satisfactory because they match the rainfall regime of the entire state, although the results from similar analyses in larger areas and with higher spatiotemporal variability in precipitation may be biased and therefore should be evaluated in more detail.

Figure 4 shows, for example, that the September hyetograph is more similar to the August hyetograph than the October hyetograph. However, this kind of similarity is not easily observed in Figure 3. Thus, this cluster analysis (Figure 4) is useful to identify this type of regional climate pattern. A simple example of how such information could help in drought (or rainy season) management is when the rainfall depths are low/high in August, similar rainfall depths may be expected in September. 
To perform spatial cluster analyses between the similarities of different precipitation time series, dendrograms and cluster spatializations in four clusters (because Paraíba has four mesoregions) were obtained based on (a) the mean monthly precipitation time series (hyetographs in Figure 5a) and (b) total monthly precipitation time series between 1998 and 2015 (hyetographs in Figure 5b). Thus, two different spatial clustering methods were used: one based on the clustering of the 187 total precipitation time series, each with 216 values (12 months $\times 18$ years), and another based on the clustering of 187 mean monthly precipitation time series, each with 12 values (one for each month). Both types of analysis were used in this study to assess whether the clusters of precipitation time series significantly changed when considering both time series based on total monthly data and on mean monthly data throughout the study period.

\section{(a) January-December}

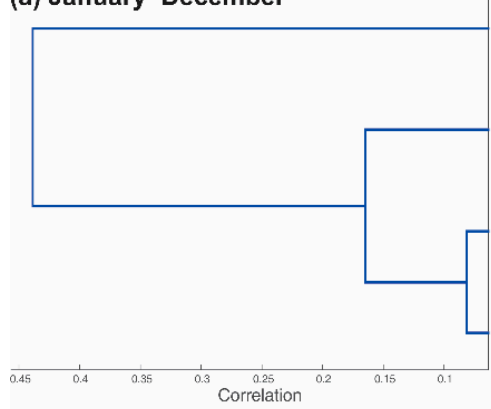

(b) 1998-2015

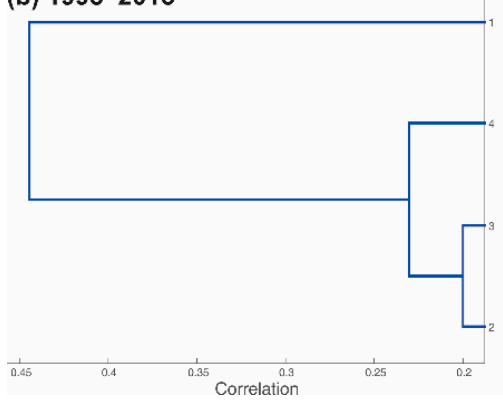

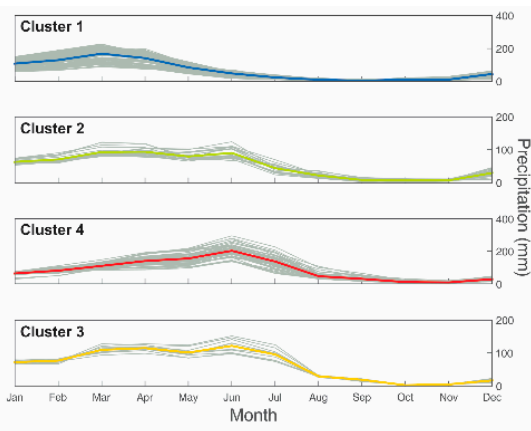
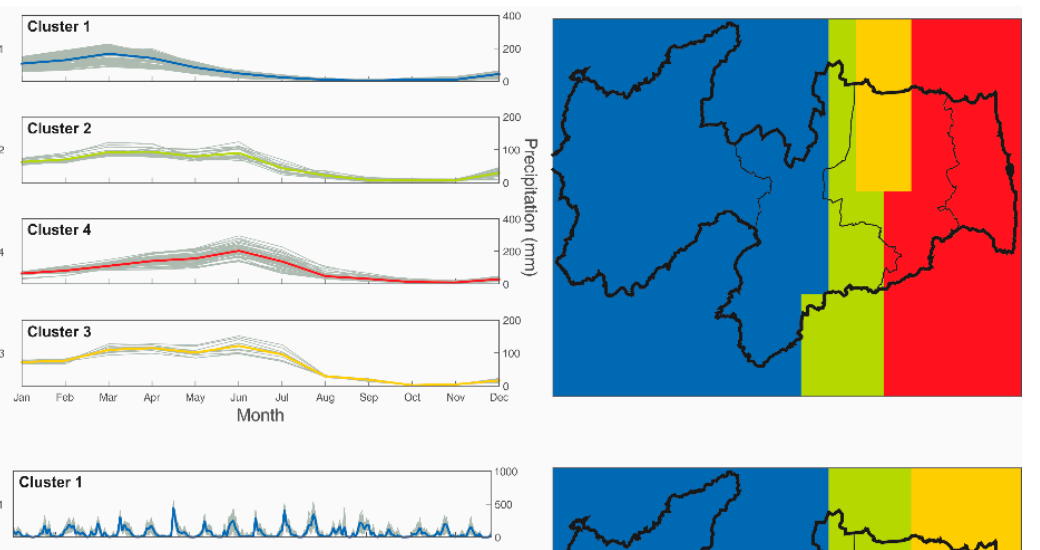

\section{Cluster 4}

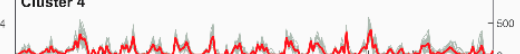

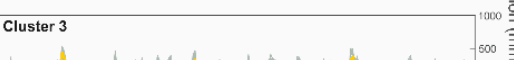

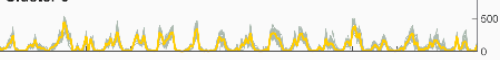
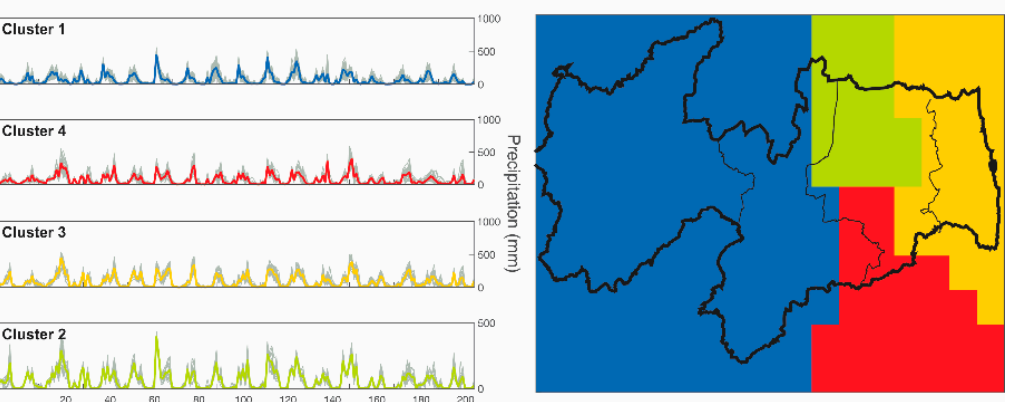

Figure 5. Dendrograms and cluster spatializations in four clusters based on (a) the mean monthly precipitation time series and (b) total monthly precipitation time series, for the analyzed period (1998-2015). On the left are the dendrograms. In the center are the hyetographs. On the right are the cluster spatial distributions.

For example, $\mathrm{P} 131$ (latitude $=-7.75^{\circ}$ and longitude $=-35.75^{\circ}$ ) and $\mathrm{P} 132$ (latitude $=-7.75^{\circ}$ and longitude $=-36.00^{\circ}$ ) belong to clusters 4 and 2, respectively, when the mean monthly precipitation time series are considered (Figure 5a). However, when the total monthly time series are considered, these two grid points belong to the same cluster (cluster 4). This means that although the total monthly rainfall pattern has been statistically similar since 1998 (cluster 4 in Figure 5b), the monthly averages have presented different patterns (cluster 2 and 4 in Figure 5a); e.g., while the monthly rainfall depths are almost constant from January to June in P132 (cluster 2 in Figure 5a), those rainfall depths slightly increase in P131 (cluster 4 in Figure 5a).

The results show, in general, a rather similar trend between monthly precipitation time series because both the mean (Figure $5 \mathrm{a}$ ) and total (Figure $5 \mathrm{~b}$ ) monthly precipitation data had a maximum correlation distance of 0.50 between time series. Conversely, despite that similarity, the clusters based on mean monthly rainfall (Figure 5a) tend to be more similar to each other than the time series based on total monthly values (Figure $5 b$ ). For a correlation distance of 0.20 , for example, only two large groups are formed when using mean monthly precipitation time series (Figure 5a), including one consisting of cluster 1, which basically encompasses the Sertão and Borborema mesoregions, and another group containing the other clusters, which encompass the Mata and Agreste Paraibano 
mesoregions. However, when using total monthly precipitation time series (Figure 5b), for the same correlation distance of 0.20, four different clusters are formed: (a) most of Sertão and Borborema (cluster 1), (b) the northern section of Agreste (cluster 2), (c) the southern section (cluster 3), and (d) the entire region of Mata Paraibana (cluster 4).

Thus, although the Sertão and Borborema mesoregions tend to behave similarly throughout the study period, regardless of the precipitation values used (mean monthly or total monthly time series), the similarity of the mesoregions Agreste and Mata Paraibana varied according to the type of time series analyzed, i.e., continuous time series of total (series with 216 records) or mean (series with 12 records) monthly values. Recent studies [37] show that performance of satellite products in capturing extreme/heavy rainfall events is not the same as regular events. However, this region is free from extreme/heavy rainfall events such as hurricanes.

The higher total rainfall values of the Mata Paraibana and Agreste mesoregions in comparison with those of the Sertão and Borborema mesoregions may possibly explain this result. Thus, those regions must have experienced some extreme precipitation events during the study period, considerably differing from the mean monthly values assessed. Hence, because they have higher monthly variations in the TRMM time series, the Mata and Agreste mesoregions differ more when using the total monthly time series (Figure 5b) than when using the mean monthly time series (Figure 5a) because all extreme events that occurred throughout the study period are captured in the total monthly time series, whereas all those unusual events are offset by a mean value for the study period in the time series of mean monthly values, thereby mitigating differences between clusters.

Furthermore, the trend observed on the coast may be related to the proximity between the mainland and the ocean, which entails high humidity in this region closest to the shore, considerably affecting the precipitation regime found there. In addition, the Borborema Plateau may be considered to be a topographic factor, that is, a natural barrier responsible for the behavior of the circulation of air masses in the region, hindering the arrival of moisture from the ocean to the semiarid region of Paraíba, directly affecting the precipitation in Sertão, Borborema, Mata Paraibana, and Agreste. These results corroborate the findings of Lyra et al. [14], who identified, when delimiting homogeneous zones of Alagoas state, the formation of clusters far from the coast and affected by the topographic factor.

Figure 6 shows the results from the cluster analysis of each month, based on the total monthly time series of each year and for each grid, in contrast to previous studies, which exclusively analyzed results similar to those shown in Figure 5. Thus, the regions with the most similar trends in each month can be identified, thereby identifying the climate systems active in the region. The specific analysis of the results for each month shows that the correlation distances between precipitation time series obtained in January in Paraíba state are small and that most of the study area is included in cluster 1 , which basically covers all the mesoregions of the state. Considering that the dissimilarity metric used in this study was the correlation distance between the trend of the time series, this clustering highlights that the precipitation in January was proportional throughout the region over the 18 years analyzed, i.e., when it rained in some region of Mata Paraibana or Borborema, for example, it also rained in the Sertão and Agreste mesoregions, albeit in different volumes. Therefore, the correlation metric was more adequate because the objective is to assess whether the time series behave similarly to each other in general and not in absolute values, which would be the case if Euclidean distance had been used as a dissimilarity metric. The results also indicate increased correlation distances between the precipitation time series analyzed and the improved spatial division of Paraíba state. In general, three large clusters exist in Paraíba state: a large cluster over the regions of Sertão and Agreste (cluster 1), another covering the northern coastal region (cluster 2), and a third cluster covering the southern section of the Mata Paraibana and Borborema regions (cluster 4). The latter two are more similar to each other, as indicated by the values obtained. In March, the correlation distances between the time series increased when compared with the values obtained for January and February, albeit at a correlation distance between time series of 0.30 for the Sertão and Borborema mesoregions (cluster 1), the precipitation of which differs from that of the Mata Paraibana (cluster 3) and Agreste Paraibano (cluster 2) mesoregions. 

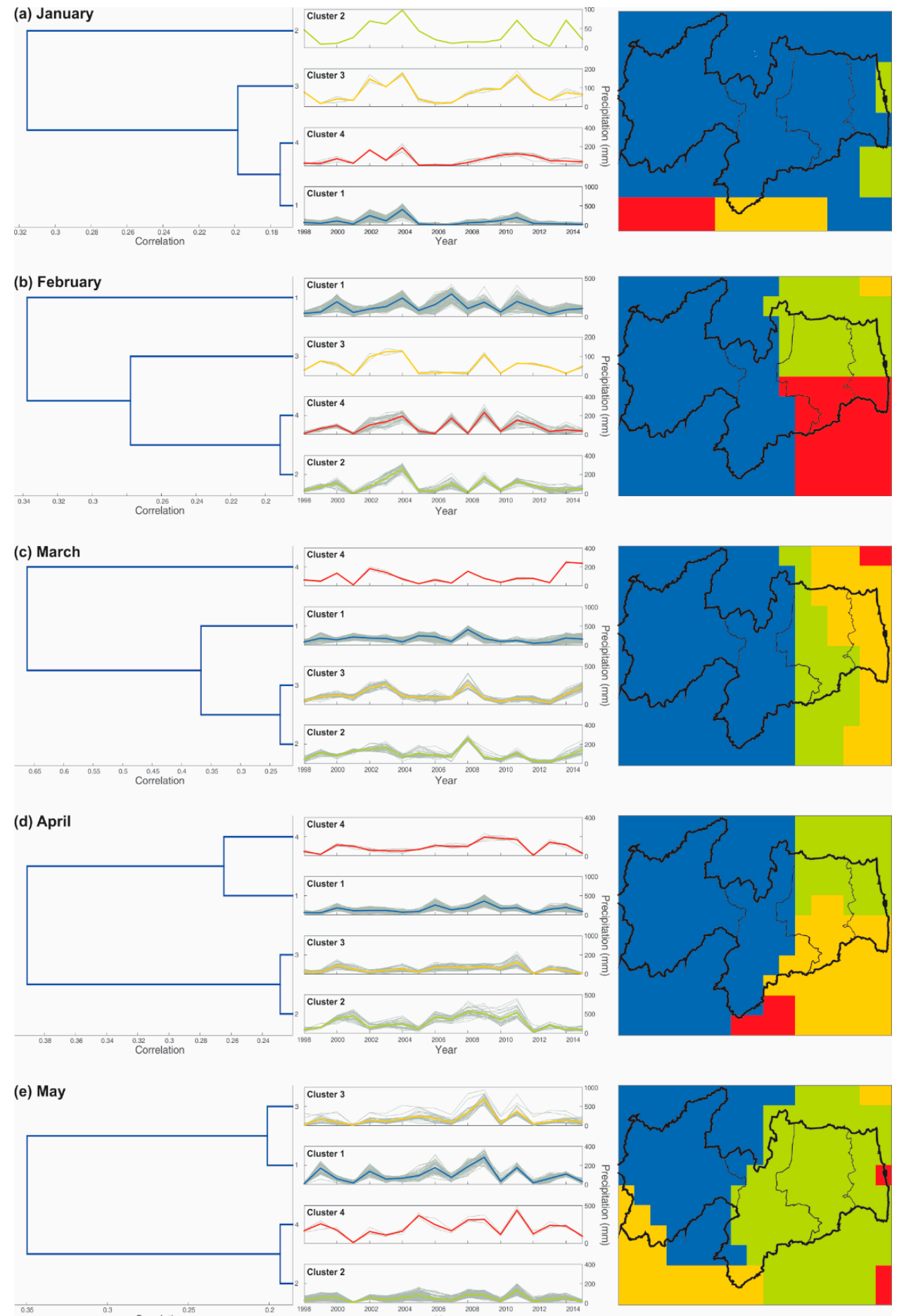

(f) June
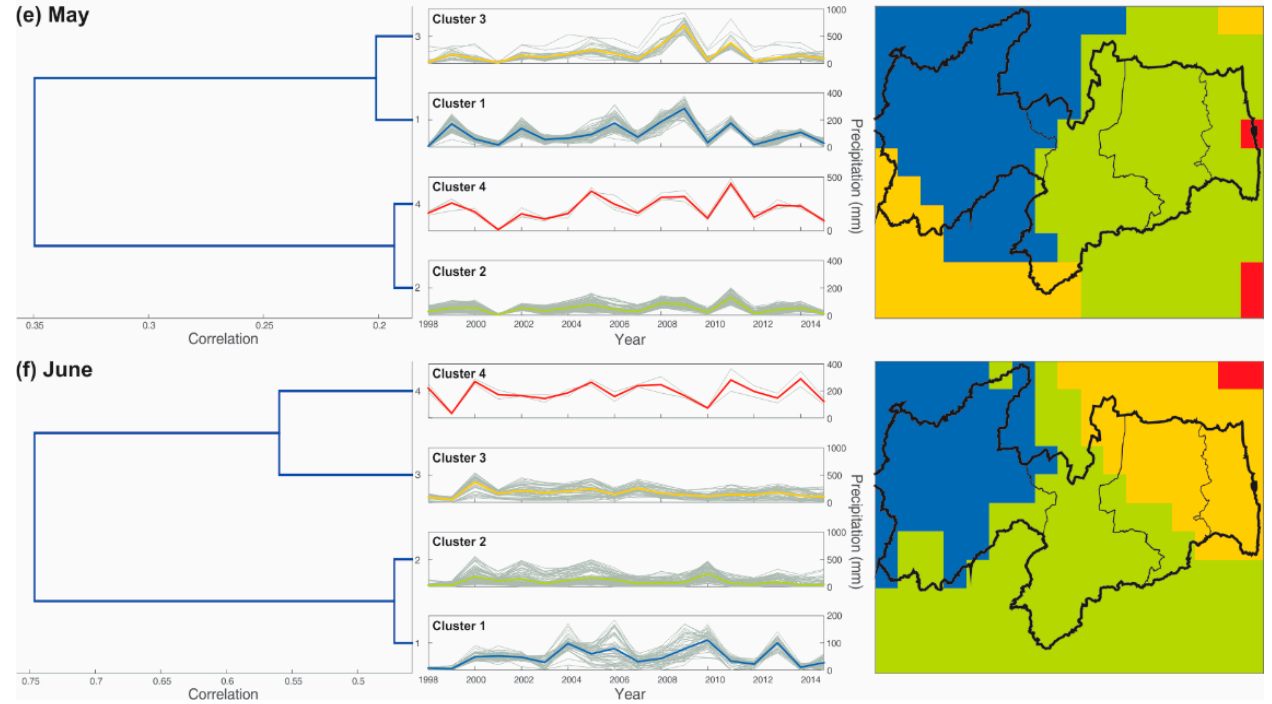

Figure 6. Cont. 
(g) July
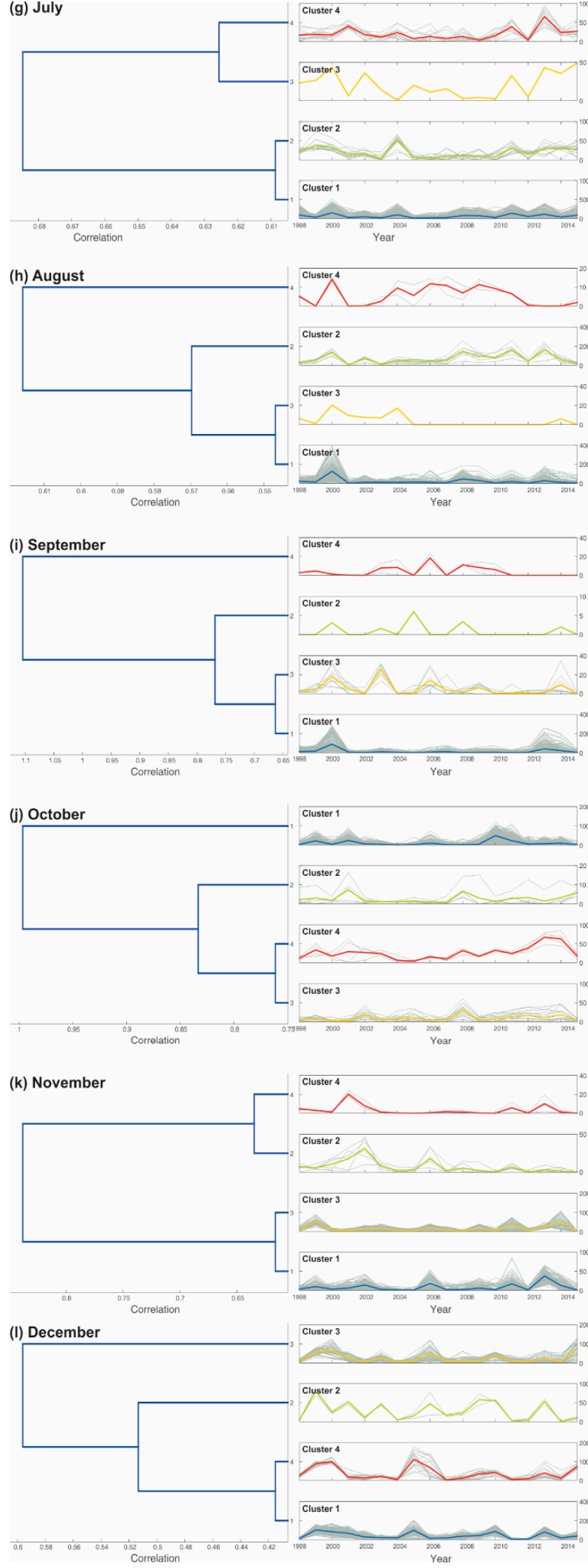
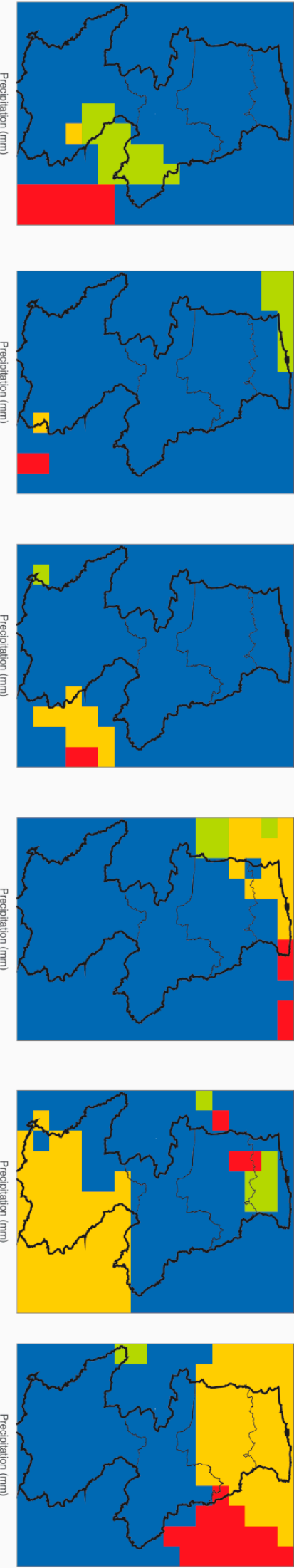

Figure 6. Cluster spatializations in four clusters and dendrograms of mean monthly precipitation time series for each month over Paraíba state (1998-2015). 
In addition, in contrast to the results for January and February, at a correlation distance of 0.20, the precipitation in the Mata and Agreste regions is classified into different groups, indicating that its trend is no longer as similar as that of previous months. The spatiotemporal precipitation trend found in April is quite similar to that found in February, and Paraíba state is basically divided into three large clusters. Cluster 1 covers the entire Sertão and Borborema regions, whereas clusters 2 and 3 cover the north and south sections of the Mata Paraibana and Agreste mesoregions, respectively.

The precipitation trend in Paraíba from January to mid-April is noticeably similar to that observed by Lyra et al. [14] when delimiting homogeneous clusters in the eastern section of Alagoas state. Conversely, in the western section, the clusters showed discordant trends. According to Moscati and Gan [7] and to Molion and Bernardo [6], rainfall concentration in this period of the year in northeastern Brazil is related to maximum displacements south of the intertropical convergence zone (ITCZ). Furthermore, upper tropospheric cyclonic vortices (UTCVs) may affect precipitation, and these climate systems are more frequently active in January and February in northeastern Brazil [38].

In May, the monthly precipitation trend in Paraíba state significantly differed from the results from January to April. Although the correlation distances between precipitation time series maintained the same order of magnitude, when adopting a correlation distance of 0.20 , for example, two large clusters are formed in the study area, namely cluster 1 , which basically covers the entire regions of Sertão da Paraibano, and cluster 2, which basically covers the Borborema, Agreste, and Mata Paraibana regions. This is one of the few situations in which the Borborema and Sertão da Paraibano regions are not included in the same cluster, which indicates the rather unusual behavior of May compared with the other months of the year because that is the last month of the rainy season (autumn).

This peculiarity of the autumn season (March, April, and May) may be associated with the presence of instability lines (ILs), which propagate inland accompanying the seasonal movement of the ITCZ, considering that the frequency of ILs is higher in May in northeastern Brazil. The results show a relationship between rainfall and regions with clusters located in western Paraíba. Such a phenomenon was also observed in homogeneous groups classified by Lyra et al. [14] in the eastern section of Alagoas state, the precipitation trend of which is more similar to that observed in previous months, especially in the semiarid section.

June marks the beginning of a period during which the correlation distances considerably increase, and that period lasts until mid-November, that is, the correlation distances between time series are significantly longer than those found in the analysis of the first semester. Accordingly, at a correlation distance of 0.50 , two large groups are formed in the study area, one consisting of cluster 3, covering the Mata Paraibana region and the northern section of Agreste, and another large group formed by clusters 1 and 2, which basically cover the rest of the state. Notwithstanding, the precipitation trend in June is also rather unusual, with considerable differences between Sertão da Paraibano (cluster 1), Borborema and the southern section of Agreste (cluster 2) on one hand, and Mata Paraibana and northern Agreste (cluster 3) on the other hand.

Importantly, from June to August, the rainfall on the coast of Paraíba matches the undulating variations in winds and pressure from the South Atlantic, which generate a displacement from east to west from the coast of Africa and reach the Zona da Mata of northeastern Brazil, resulting in the easterly wave disturbances (EWDs) [6,38]. At the beginning of the second semester, once again, the correlation distances between precipitation time series are very long, with a differentiation of the trend of different clusters already at a correlation distance of 0.60 . However, a more detailed analysis shows that most of the time series spaced over the study area form cluster 1, except the southern sections of Sertão (cluster 3) and Borborema (cluster 2).

The precipitation trend in August, regarding the clustering of homogeneous regions, is similar to that in July because, although the precipitation time series show long correlation distances from each other, most of Paraíba state shows a precipitation trend similar to that of cluster 1. Conversely, in contrast to the configuration of July, at a correlation distance of 0.55 , the northeastern coastal region of Paraíba (cluster 2) tends to behave differently from the rest of the state. 
In September, the entire Paraíba state is clustered in a single group according to the behavior of precipitation time series. Cluster 1 is the group that characterizes the homogeneous precipitation of the entire Paraíba state, indicating similarity in precipitation trends. In this case, the correlation distances obtained in this month are long. Therefore, at shorter correlation distances, more clusters will likely form and spread throughout Paraíba state. However, because the divisions were based on four clusters in the present study, corresponding to the number of mesoregions of the state, a single cluster basically characterizes the precipitation in September.

Similar to September, October shows some of the longest correlation distances between precipitation time series found in Paraíba state. In both months, the precipitation trends in specific areas tend to be completely different, as is the case for cluster 1 and the group formed by clusters 2,3 , and 4 in October, for example. In addition, similarly to August, cluster 1 tends to basically cover all mesoregions of Paraíba, and the precipitation trend also unusually differs in the northeastern coastal section of Paraíba (cluster 3).

In November, the precipitation trend is quite unusual, with the formation of clusters that spread across all mesoregions of Paraíba. In general, cluster 1 covers most of Borborema and Agreste of Paraíba, clusters 2 and 4 cover most of the Mata Paraibana region, and, lastly, cluster 3 mostly covers the Sertão Paraibano. November, therefore, shows a more diverse precipitation trend than other months because the precipitation in Sertão behaves differently from that in Borborema, similar to May and June, and Borborema in turn is more directly related to the Agreste region.

The analysis of the spring months (September, October, and November) shows a decrease in rainfall, especially in October, which may be related to the movement of the ITCZ, as explained by Moscati and Gan [7] and by Molion and Bernardo [6]. Those authors observed that when moving north, the formation of rain clouds tends to decrease, causing drought in the semiarid region. Another key issue is the modulation of the behavior of atmospheric systems and of the ITCZ by sea surface temperature (SST) anomalies through the El Niño Southern Oscillation (ENSO) phenomenon [6,39,40].

Considering the effect of the ENSO phenomenon on the precipitation in Paraíba, Menezes et al. [40] state that the conditions of SST anomalies are more strongly affected by the Tropical Atlantic in the eastern regions of the state, whereas SST anomalies are more related to the Equatorial Pacific in central and western Paraíba. Lastly, in December, the precipitation trend tends to strongly differ between the Sertão and Borborema regions (cluster 1) on one hand and the Agreste and Mata Paraibana mesoregions (cluster 3) on the other hand. Overall, the results also show that these differences in precipitation trend are very high because, for example, at the correlation distance of 0.60 , the region defined by cluster 3 tends to show a behavior different from all other regions of the study area.

\section{Conclusions}

The study was conducted with the primary aim of understanding the spatiotemporal variability in precipitation over Paraíba state, using TRMM 3B42 satellite data over a period of 18 years (1998-2015). Based on those data, a cluster analysis was applied to precipitation data from the TRMM satellite to identify the precipitation trends in both time and space in more detail.

The temporal analysis showed differences in the precipitation trend of the entire study area between months throughout the year, forming nine different groups of months. The spatial analysis identified two large groups in the study area: one formed by the Sertão and Borborema mesoregions and another formed by the Agreste and Mata Paraibana mesoregions. In addition, the precipitation trend varied more between the Mata Paraibana and Agreste regions than between the Sertão and Borborema regions, which may be related to variations in the rainfall levels of each region.

The present study also agrees with previous studies, which identified climate systems active in northeastern Brazil throughout the respective study periods. Furthermore, the altitude factor contributes to an increased inhibition of rainfall distribution in the middle latitudes, in the steep section of the Borborema mesoregion, blocking the effects of atmospheric systems. However, altitude 
alone does not explain the rainfall regime of a region, and agents such as the ENSO phenomenon, ITCZ variation, SST, and IL, for example, are known to affect the rainfall trend in Paraíba.

In conclusion, the cluster analysis method developed in this study proved satisfactory for the clustering and identification of homogeneous regions in Paraíba state, enabling the spatiotemporal association of physical and climatological factors affecting the study area of northeastern Brazil. Such clustering and identification of homogeneous regions based on hydrometeorological variables would be useful for the water resources community to assist decision-making regarding the adoption of plans to combat the implications of drought in climatologically complex semiarid region. These types of results are valuable source of information in the context of climate studies, such as climate change mitigation policies, studies of natural disasters, and planning of human activities, and can provide the basis for several regional and local planning activities such as climate forecasts, agricultural zoning, and meteorological research programs. Based on this study, similar studies should be conducted in different study areas, albeit adequately applying clustering methods and metrics according to the characteristics of those study regions, as discussed in the present article.

Author Contributions: Conceptualization, C.A.G.S. and R.M.B.N.; methodology, C.A.G.S. and R.M.B.N.; writing - original draft preparation, R.M.B.N., C.A.G.S., and S.G.F.C.; writing-review and editing, C.A.G.S., R.M.B.N., and R.M.d.S.; funding acquisition, C.A.G.S. and R.M.d.S.

Funding: This research was funded by the National Council for Scientific and Technological Development, Brazil-CNPq, grant numbers 304213/2017-9, 304540/2017-0 and 408631/2016-3. This study was also financed in part by the Brazilian Agency for the Improvement of Higher Education (Coordenação de Aperfeiçoamento de Pessoal de Nível Superior-CAPES)_Fund Code 001 and the Federal University of Paraíba.

Acknowledgments: The data from the Tropical Precipitation Measuring Mission (TRMM), NASA/JAXA, are gratefully acknowledged.

Conflicts of Interest: The authors declare no conflict of interest.

\section{References}

1. Santos, C.A.G.; Freire, P.K.M.M. Analysis of precipitation time series of urban centers of northeastern Brazil using wavelet transform. Int. J. Environ. Chem. Ecol. Geol. Geophys. Eng. 2012, 6, 845-850.

2. Martino, G.; Fontana, N.; Marini, G.; Singh, V.P. Variability and trend in seasonal precipitation in the continental United States. J. Hydrol. Eng. 2013, 18, 630-640. [CrossRef]

3. Silva, R.M.; Santos, C.A.G.; Moreira, M.; Corte-Real, J.; Silva, V.C.L.; Medeiros, I.C. Rainfall and river flow trends using Mann-Kendall and Sen's slope estimator statistical tests in the Cobres River basin. Nat. Hazards 2015, 77, 1205-1221. [CrossRef]

4. Santos, C.A.G.; Brasil Neto, R.M.; da Silva, R.M.; Santos, D.C. Innovative approach for geospatial drought severity classification: A case study of Paraíba state, Brazil. Stoch Environ. Res Risk Assess 2018. [CrossRef]

5. Farhangi, M.; Kholghi, M.; Chavoshian, S.A. Rainfall trend analysis of hydrological sub-basins in western Iran. J. Irrig. Drain. Eng. 2016, 142, 1-11. [CrossRef]

6. Molion, L.C.B.; Bernardo, S.O. Uma revisão da dinâmica das chuvas no Nordeste brasileiro. Rev. Bras. Meteorol. 2002, 17, 1-10.

7. Moscati, M.C.D.L.; Gan, M.A. Rainfall variability in the rainy season of semiarid zone of Northeast Brazil (NEB) and its relation to wind regime. Int. J. Climatol. 2007, 27, 493-512. [CrossRef]

8. Marengo, J.A.; Alves, L.M.; Soares, W.R.; Rodriguez, D.A.; Camargo, H.; Riveros, M.P.; Pabló, A.D. Two contrasting severe seasonal extremes in tropical South America in 2012: Flood in Amazonia and drought in Northeast Brazil. J. Clim. 2013, 26, 9137-9154. [CrossRef]

9. Marengo, J.A.; Alves, L.M.; Alvala, R.C.S.; Cunha, A.P.; Brito, S.; Moraes, O.L.L. Climatic characteristics of the 2010-2016 drought in the semiarid Northeast Brazil region. An. Acad. Bras. Ciências 2017, 90, 1973-1985. [CrossRef] [PubMed]

10. Cunha, A.P.M.A.; Tomasella, J.; Ribeiro-Neto, G.G.; Brown, M.; Garcia, S.R.; Brito, S.B.; Carvalho, M.A. Changes in the spatial-temporal patterns of droughts in the Brazilian Northeast. Atmos. Sci. Lett. 2018, 19, 855-862. [CrossRef] 
11. Brito, S.S.; Cunha, A.P.; Cunningham, C.C.; Alvalá, R.C.; Marengo, J.A.; Carvalho, M.A. Frequency, duration and severity of drought in the Semiarid Northeast Brazil region. Int. J. Climatol. 2018, 38, 517-529. [CrossRef]

12. Rad, A.M.; Khalili, D. Appropriateness of clustered raingauge stations for spatio-temporal meteorological drought applications. Water Resour. Manag. 2015, 29, 4157-4171. [CrossRef]

13. Unal, Y.; Kindap, T.; Karaca, M. Redefining the climate zones of Turkey using cluster analysis. Int. J. Climatol. 2003, 23, 1045-1055. [CrossRef]

14. Lyra, G.B.; Oliveira-Júnior, J.F.; Zeri, M. Cluster analysis applied to the spatial and temporal variability of monthly rainfall in Alagoas state, Northeast of Brazil. Int. J. Climatol. 2014, 34, 3546-3558. [CrossRef]

15. Cattani, E.; Merino, A.; Levizzani, V. Evaluation of monthly satellite-derived precipitation products over East Africa. J. Hydrometeorol. 2016, 17, 2555-2573. [CrossRef]

16. Corporal-Lodangco, I.L.; Leslie, L.M. Defining Philippine Climate Zones Using Surface and High-Resolution Satellite Data. Procedia Comput. Sci. 2017, 114, 324-332. [CrossRef]

17. Teodoro, P.E.; Oliveira-Júnior, J.F.; Cunha, E.R.; Correa, C.C.G.; Torres, F.E.; Bacani, V.M.; Gois, G.; Ribeiro, L.P. Cluster analysis applied to the spatial and temporal variability of monthly rainfall in Mato Grosso do Sul State, Brazil. Meteorol. Atmos. Phys. 2016, 128, 197-209. [CrossRef]

18. Kummerow, C.; Simpson, J.; Thiele, O.; Barnes, W.; Chang, A.T.; Stocker, E.; Adler, R.F.; Hou, A.; Kakar, R.; Wentz, F; et al. The status of the Tropical Rainfall Measuring Mission (TRMM) after two years in orbit. J. Appl. Meteorol. 2000, 39, 1965-1982. [CrossRef]

19. Collischonn, B.; Allasia, D.; Collischonn, W.; Tucci, C.E.M. Desempenho do satélite TRMM na estimativa de precipitação sobre a bacia do Paraguai Superior. Rev. Bras. Cartogr. 2007, 59, 93-99.

20. Huffman, G.J.; Bolvin, D.T. TRMM and Other Data Precipitation Data Set Documentation. Global Change Master Directory; NASA: Washington, DC, USA, 2017; 45p.

21. Huffman, G.J.; Bolvin, D.T.; Nelkin, E.J.; Wolff, D.B. The TRMM multisatellite precipitation analysis (TMPA): quasi-global, multiyear, combined-sensor precipitation estimates at fine scales. J. Hydrometeorol. 2007, 8, 38-55. [CrossRef]

22. Jiang, S.; Ren, L.; Zhou, M.; Young, B.; Zhang, Y.; Ma, M. Drought monitoring and reliability evaluation of the latest TMPA precipitation data in the Weihe River Basin, Northwest China. J. Arid Land 2017, 9, 256-269. [CrossRef]

23. Pereira, G.; Silva, M.E.S.; Moraes, E.C.; Cardozo, F.S. Avaliação dos dados de precipitação estimados pelo satélite TRMM para o Brasil. Rev. Bras. Recur. Hídricos 2013, 18, 139-148. [CrossRef]

24. Santos, C.A.G.; Brasil Neto, R.M.; Passos, J.S.A.; Silva, R.M. Drought assessment using a TRMM-derived Standardized Precipitation Index for the Upper São Francisco River basin, Brazil. Environ. Monit. Assess. 2017, 189, 1-19. [CrossRef] [PubMed]

25. Santos, C.A.G.; Brasil Neto, R.M.; Silva, R.M.; Passos, J.S.A. Integrated spatiotemporal trends using TRMM 3B42 data for the Upper São Francisco River basin, Brazil. Environ. Monit. Assess. 2018, 190, 1-20. [CrossRef] [PubMed]

26. Islam, M.N.; Uyeda, H. Use of TRMM in determining the climatic characteristics of rainfall over Bangladesh. Remote Sens. Environ. 2007, 108, 264-276. [CrossRef]

27. Omranian, E.; Sharif, H.O. Evaluation of the Global Precipitation Measurement (GPM) satellite rainfall products over the Lower Colorado River basin, Texas. J. Am. Water Resour. Assoc. 2018, 54, 882-898. [CrossRef]

28. Soares, A.S.D.; Da Paz, A.R.; Piccilli, D.G.A. Avaliação das estimativas de chuva do satélite TRMM no Estado da Paraíba. Rev. Bras. Recur. Hídricos 2016, 21, 288-299. [CrossRef]

29. Macedo, M.J.H.; Guedes, R.V.S.; Souza, F.A.S.; Dantas, F.R.C. Analysis of the standardized precipitation index for the Paraíba state, Brazil. Ambiente Água 2010, 5, 204-214. [CrossRef]

30. Alvares, C.A.; Stape, J.L.; Sentelhas, P.C.; Gonçalves, J.L.M.; Sparovek, G. Köppen's climate classification map for Brazil. Meteorol. Z. 2014, 22, 711-728. [CrossRef]

31. Francisco, P.R.M.; Medeiros, R.M.; Tavares, A.L.; Santos, D. Variability space-temporal of annual precipitation of wet and dry period in the Paraíba state. J. Hyperspectral Remote Sens. 2016, 6, 1-9. [CrossRef]

32. Kousky, V.E. Frontal influences on Northeast Brazil. Montly Weather Rev. 1979, 107, 1140-1153. [CrossRef]

33. De Carvalho, M.A.V.; Oyama, M.D. Atlantic Intertropical Convergence Zone width and intensity variability: observational aspects. Rev. Bras. Meteorol. 2013, 28, 305-316. [CrossRef] 
34. Costa, R.L.; de Souza, E.P.; Silva, F.D.D. An application of a thermodynamic theory on studying an Upper-Tropospheric Clyclonic Vortex over northeast Brazil. Rev. Bras. Meteorol. 2014, 29, 96-104. [CrossRef]

35. Moura, G.B.A.; de Aragão, J.O.R.; de Melo, J.S.P.; da Silva, A.P.N.; Giongo, P.R.; Lacerda, F.F. Relationship between the rainfall of the eastern Northeast of Brazil and the ocean temperature. Rev. Bras. Eng. Agríc. Ambient. 2009, 13, 462-469. [CrossRef]

36. Santos, C.A.G.; Kisi, Ö.; Silva, R.M.; Zounemat-Kermani, M. Wavelet-based variability on streamflow at 40-year timescale in the Black Sea region of Turkey. Arab. J. Geosci. 2018, 11, 169. [CrossRef]

37. Omranian, E.; Sharif, H.O.; Tavakoly, A.A. How well can Global Precipitation Measurement (GPM) capture hurricanes? Case study: Hurricane Harvey. Remote Sens. 2018, 10, 1150. [CrossRef]

38. Ferreira, A.G.; Mello, N.G.S. Principais sistemas atmosféricos atuantes sobre a região Nordeste do Brasil e a influência dos oceanos Pacífico e Atlântico no clima da região. Rev. Bras. Climatol. 2005, 1, 15-28. [CrossRef]

39. Almeida, H.A.; Medeiros, E.A. Variabilidade no regime pluvial em duas mesorregiões da Paraíba e sua relação com o fenômeno El Niño Oscilação Sul. J. Environ. Anal. Prog. 2017, 2, 177-185. [CrossRef]

40. Menezes, H.E.A.; Brito, J.I.B.; Santos, C.A.C.; Silva, L.L. Relationship between the surface temperature on the tropical oceans and the duration of dry spells in the Paraíba State. Rev. Bras. Meteorol. 2008, 23, 152-161. [CrossRef]

(C) 2019 by the authors. Licensee MDPI, Basel, Switzerland. This article is an open access article distributed under the terms and conditions of the Creative Commons Attribution (CC BY) license (http://creativecommons.org/licenses/by/4.0/). 